\title{
テーパ管を流動する可視化モデルコンクリートの 乱れ計測システム \\ MEASUREMENT SYSTEM FOR FLUCTUATION OF CONCRETE FLOW IN TAPERED PIPE WITH HELP OF VISUALIZATION TECHNIQUE
}

\author{
橋本 親 典*・堀口和弘**・丸山久一***・清 水敬二**** \\ By Chikanori HASHIMOTO, Kazuhiro HORIGUCHI, Kyuichi MARUYAMA and Keiji SHIMIZU
}

\begin{abstract}
In order to evaluate the deformability of fresh concrete flowing in pipes, a new system was developed in this paper to obtain the information about movements of mortar and coarse aggregates with help of the visualization technique.

For visualizing the concrete flow, concrete was replaced by the model concrete made of transparent mortar and specially designed coarse aggregates, and the pipe was made by the transparent plastic material.

Movements of mortar and coarse aggregates were recorded by the Video System, and were traced and analyzed by the Graphic Analyzer.

It was observed that there existed the fluctuation in concrete flow at the tapered portion of pipe. Since the fluctuation should be concerned with the deformability of fresh concrete, the index for evaluating the degree of fluctuation was proposed.

Keywords: fluctuation, deformability, visualization technique, tapered pipe, model concrete
\end{abstract}

\section{1. 序論}

コンクリートポンプ工法は, 現場内小運搬作業として, 仮設設備の節減, 工期の短縮等を可能とするので, 現場 においては省力化による経済的波及効果が大きく, 土 木・建築の分野を問わず広く普及している1).また，『コ ンクリートのポンプ施工指針 (案) 』2)が土木学会で作成 されており, 施工, 圧送計画, 品質管理などについて, 新しい指針制定への第一歩となっている.これらの現状 からみて, コンクリートポンプ工法は, 今や完全に施工 現場のルーチンワークとして定着しているといえる.

しかし，圧送作業の能率に大きな障害となっている管 内閉塞事故については, その発生メカニズムや発生条件 に関する理論的研究が十分でなく, 圧送計画の段階にお いては管内閉塞事故に対する安全基準を確立するまでに 至っていないのが現状である。したがって, 管内閉塞事 故を避けるあまり, 配合のうえでは, 単位水量, 単位セ メント量や $s / a$ を必要以上に増加する傾向があり, そ

* 正会員 工修 長岡技術科学大学助手 建設系 ( テ940-21 新潟県長岡市上富岡 1603-1)

** 正会員 工修 大阪府庁 （₹581 大阪府八尾市庄内町 2-1-36)

*** 正会員 Ph. D. 長岡技術科学大学助教授 建設系 (テ940-21 新潟県長岡市上富岡 1603-1)

**** 正会員 農博 長岡技術科学大学教授 建設系 (同上)
の結果, 硬化コンクリートの耐久性にも悪影響を及ぼす ことになる11.コンクリートポンプ工法において，コン クリートの品質を変えることなく，かつ十分な施工をし てゆくためには，管内閉塞機構の解明が急務となってき ている.

著者らは,これまでに，管内閉塞現象のメカニズムを 解明する目的で，まず，フレッシュコンクリートの管内 流動状況を可視化し，管内閉塞現象の発生過程における 粗骨材粒子群とモルタル相の力学的挙動を詳細に観察・ 記録するための実験手法を開発した ${ }^{3), 4)}$. 次に, 実験室 規模の小型ポンプモデルを用いて，この可視化実験手法 をテーパ管圧送実験に適用し，テーパ管出口付近で粗骨 材粒子群がアーチ構造を形成し, 閉塞に至る過程をビデ オ撮影および写真撮影することに成功した.

これらの管内閉塞過程に関する情報から, 管内流動し ているコンクリートが閉塞状態に近づくに従って, コン クリート中の一部の粗骨材粒子群が微小振動を起こしな がら, 流動していることが観察された。 また，その微小 振動の影響で, 粗骨材粒子群とその周辺のモルタル相の 流速が変動していることも確認された。

さらに，可視化モデルコンクリートの粗骨材とモルタ ルの容積比を増大させたとき, 管内閉塞が発生する容積 比に近くなると, 粗骨材粒子群とその周辺のモルタル相 
の微小振動現象の発生頻度が高くなり, 流速の変動は大 きくなることが観察された。この一連の粗骨材粒子群と モルタル相に関する挙動は，管内閉塞の前兆現象と考え られ，この前兆現象の定量的評価が，実際のフレッシュ コンクリートの閉塞機構解明の手がかりとなると予想さ れる.

本研究は, “可視化モデルコンクリート”という限定 つきではあるが，テーパ管内を流動するフレッシュコン クリートの変形性能に対する新しい指標の確立を目的と し，粗骨材粒子群とその周辺のモルタル相の流速の変動 を定量化する計測システムを開発したものである ${ }^{5), 6)}$.

なお, 本研究で用いた可視化実験手法については, 参 考文献 3）において, 可視化モデルコンクリートに使用 する材料の選定, 可視化モデルコンクリートと実際のフ レッシュコンクリートとの相違点および可視化モデルコ ンクリートによる管内閉塞現象に対するシミュレーショ ン実験の妥当性等について詳細に検討してあるので, 本 論文では省略する。

\section{2. フレッシュコンクリートの乱れ特性と変形 性能の関係}

これまでの実験的研究から, 配合上で粗骨材とモル夕 ルの容積比 $\left(V_{g} / V_{m}\right)$ が, ある限界值 (以後, 限界閉塞 容積比とする）以上になるとテーパ管，ベント管や分岐 管等の断面形状が変化している圧送管において管内閉塞 現象が発生することが明らかになっている7). 写真一1 は，可視化モデルコンクリートの配合上の粗骨材とモル タルの容積比が，限界閉塞容積比であるとき,テーパ管 内で粗骨材粒子群とモルタル相の間に相対速度が発生し ている状態を撮影したものである．テーパ管出口付近に おいて, 大粒径の粗骨材粒子群の周辺でモルタル相のト レーサー粒子 (発泡スチロール粒子) が白い系をひくよ うにみえる.これは，この部分のモルタル相の流速が， 他のモルタル相や粗骨材粒子群よりも非常に速く流動し ていることを示している. なお，写真撮影は，モーター ドライブ方式による連続速写装置を用いた．連続速写の 撮影条件は，レンズ：100 mm，F 4，フィルム：モノ クロ ASA 400, カメラシャッタースピード : 1/125, 絞 り : 4, モータードライブ速度 : 6 コマ/s, 撮影距離 1 $\mathrm{m}$ である.

これにより, 着目している粗骨材粒子群とモルタル相 の間には，相対速度が生じていることが確認できる．こ れは，テーパ管内を可視化モデルコンクリートが流動す る際，粗骨材粒子が管壁あるいは他の粗骨材粒子と衝突 し，回転あるいは滑動することによって粗骨材粒子間の 距離が減少し, その間に存在するモルタル相の流速が速 くなるためと考えられる。
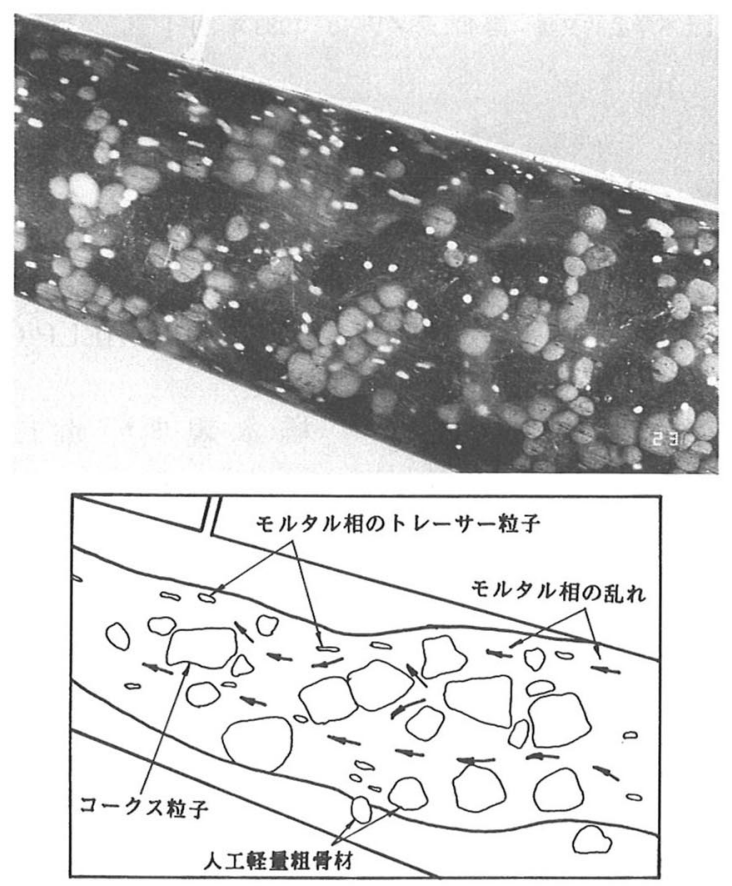

写真一1 テーパ管を流動する可視化モデルコンクリート

また，可視化実験のビデオ記録を通常の再生速度より 遅く再生し, 詳細に観察すると, 写真の例とは逆に, 粗 骨材粒子間の距離が増加し，その間のモルタル相の流速 が遅くなる現象も観察されている．さらに，テーパ管の 出口付近ほど，粗骨材粒子やモルタル相のトレーサー粒 子が微小に振動しながら流動していることが認められ た.

著者らが提案した可視化実験手法 ${ }^{3)}$ では，可視化モデ ルコンクリートと実際のフレッシュコンクリートとの力 学的相似条件として, 静的材料分離に対する抵抗性を取 り上げ，それが等しくなるよう種々の実験条件を決定し ている.したがって，実際のフレッシュコンクリートが テーパ管等の管形状の変化に伴い変形を強いられる際の 流動状況は，可視化モデルコンクリートにおける粗骨材 粒子群とモルタル相の挙動として，ほぼ表わせるものと 考えられる.

そこで, 本研究では, 圧送管の形状変化に伴って, 粗 骨材粒子群およびモルタル相の流速に変動が生じる現象 を，フレッシュコンクリートの乱れ特性と定義する．乱 れの大きさは，粗骨材粒子群とモルタル相が混合し 1 相 系流体として流動するときの断面平均流速からの変動で 表わすものとする.

また，管形状の変化に伴うモルタル相中の粗骨材粒子 群の動きやすさ，あるいは粗骨材粒子相互の相対移動の しやすさをフレッシュコンクリートの変形性能と定義 
し,変形性能はこの乱れの大きさに依存するものとする.

次に，管内流動状態のフレッシュコンクリートに発生 する乱れ特性とフレッシュコンクリート自体が有する変 形性能の関係について考察する．図一1は，乱れ特性と 変形性能の関係，および管内閉塞過程において発生する 諸現象について模式的に説明したものである.

フレッシュコンクリートが圧送管内を流動するとき, モルタル相の中を粗骨材粒子群が相対位置を変えながら モルタル相と一体化して流動するために，ある大きさを 有する “乱れ”が発生する。言い換えれば，モルタル相 の中で，あるいはモルタル相を間に介して，粗骨材粒子 相互である程度の相対移動や回転等の自由度を有してい ることがスムーズな流動のための必要条件之考えられ る.

また，フレッシュコンクリート自体は，その使用材料 の特性, 配合や配管条件等で決定される，良好なポンプ 圧送性能を発揮することができる変形性能,つまり, “乱 れ”を許容できる限界值を有すると考えられる.

通常の良好なポンプ圧送現場においては，この配管内 で発生する “乱れ” の大きさは, コンクリート固有の“乱 れ”の許容限界値に比べ小さいものと考えられる.

これに対して, 不安定圧送や閉塞事故が発生するとき は，配管内で発生する“乱れ”の大きさは，コンクリー 卜固有の “乱れ” の許容限界值以上となると考えられる.

流動状態において発生するフレッシュコンクリートの “乱れ”の大きさが, そのコンクリート自体が有する“乱 れ”の許容限界値以上になると, 何らかのきっかけで, 粗骨材粒子群の流動速度が零になり, 粗骨材粒子群が集 積する可能性がきわめて大きくなる．ただし，この現象 が生じる可能性は, 確率論的であって, “乱れ”がある 限界値を越すと, 確定論的に必ず発生するものではない。

“乱れ”が許容限界值を越えると，この粗骨材粒子群

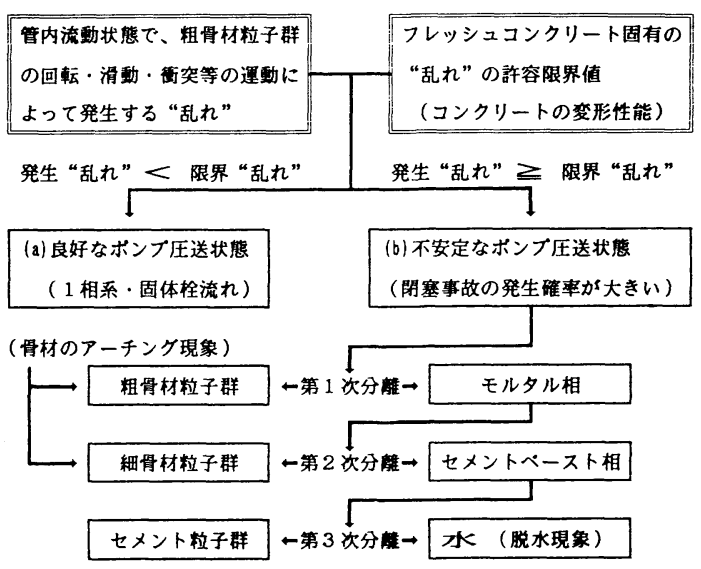

図一1 フレッシュコンクリートの乱れ特性と変形性能の関係
の集積体近傍のモルタル相の流動速度が瞬間的に非常に 大きくなり,さらに粗骨材粒子群の集積度が増大し, 粗 骨材粒子とモルタル間の材料分離が発生する（図一1 第 1 次分離).その結果, 粗骨材粒子群のアーチング構造 が形成される.

アーチングが形成された瞬間は，モルタル相の速度が 最大になるが，次の瞬間には，モルタル相の通過可能断 面積が急激に縮小してくるため，モルタル相において細 骨材粒子群のアーチングが形成される。したがって，細 骨材粒子とセメントペースト間の材料分離が生じる（図 -1 第 2 次分離).

同様に，セメントペースト相において，セメント粒子 群のアーチングが形成され，セメント粒子と水間の材料 分離が生じる（図一1第 3 次分離）.

これらの分離現象は，連続的に進行すると考えられ， 閉塞事故が発生したポンプ圧送現場では, 脱水現象 ${ }^{11}$ と いう形で観察される.

以上の議論から，フレッシュコンクリートの乱れ特性 は，管内閉塞現象の前兆として関連づけられるもので あって, 閉塞機構を解明するためには, 閉塞発生前のフ レッシュコンクリートの乱㭙性を把握することが必要 となる.

3. 可視化モデルコンクリートにおける粗骨材 粒子群とモルタル相の乱れ特性に関する計 測システム

\section{（1）本計測システムの特徴}

フレッシュコンクリートのポンプ圧送実験に関する既 往の研究では,管内流動を定量的に表わす物理量として, 圧送管の管内圧力の時間的, 位置的変動を取り扱った研 究が多い ${ }^{8)}$. 一般には, 圧送管の側壁に圧力センサーを 取り付けたものが多いが, 圧力センサ一面に直接, 粗骨 材粒子が接触すると急激に圧力が増大するために，平均 的な管壁圧力を測定するには十分とはいえない，ただ， 圧力センサーの感度と管壁圧力の大きさおよび圧力損失 の程度を考慮すると, 現場圧送に近い圧送量を対象とす れば，精度よく圧力損失を測定することができる．しか し, 実験室規模の小型ポンプ圧送実験では, 圧力損失が 小さいために管壁圧力による流動状態の変化を定量的に 計測することは不可能である．管壁圧力の代わりに，ピ ストン全面圧を測定することにより, 流動状態の変化を 計測しようとする試みもなされている"が，この方法で は局所的変化を把握することはできない.

これに対して, 本研究で開発した計測システムは, 可 視化実験手法の導入により, 可視化モデルコンクリート の管内流動状態において, 計測する対象物を明確に目視 観察することができる. したがって, 可視化モデルコン 
クリートの管内流動と実際のフレッシュコンクリートの 流動が同程度であると仮定できれば, 実際のフレッシュ コンクリートの管内流動における粗骨材粒子の速度ベク トルやモルタル相の流速ベクトルを直接二次元的に計 測・予測することができるといえる.

フレッシュコンクリートの管内流動状態の変化を示す 物理量を考えた場合, 各断面位置の管壁圧力ゃピストン 全面圧はコンクリートを構成している各要素の流動状態 の変化を平均化し, 間接的に表現した物理量といえる.

一方, 粗骨材粒子やモルタル相のトレーサー粒子の変化 を測定し, その結果得られた速度ベクトルは, 粗骨材粒 子群やモルタル相の流動状態の変化を直接表現する物理 量である.つまり, 本研究で提案する計測システムは, 実際のフレッシュコンクリートを対象とした従来の管内 流動計測システムでは測定することが不可能な物理量

(粗骨材粒子の速度ベクトルとモルタル相の流速ベクト ル）を，モデルコンクリートに置き換えることによって 測定可能にした計測システムといえる.

\section{（2）計測システムの概要}

図一2に, 本研究で開発した可視化モデルコンクリー トにおける粗骨材粒子群とモルタル相の乱れ特性に関す る計測システムの概要を示す. 乱れは, 2. で定義した ように，1相系流体とみなしたときの断面平均流速から の変動で表わすものとする.ここで, 実際に計測する物 理量は, 粗骨材粒子群とモルタル相の各トレーサー粒子 の各時刻の変位べクトルである.

本計測システムでは，テーパ管壁面近傍を運動するト レーサー粒子の軌跡を, 二次元平面座標系に投影してい る.このため, 乱れ特性の評価を, 壁面のトレーサー粒 子に対して行い，壁面の情報からテーパ管全体の挙動を 推測するものである．可視化実験から壁面を運動するト レーサー粒子が管内部方向で出入りすることがほとんど ないことが観察されているので, 本計測システムでは, 乱れの評価に対して奥行き方向の乱れは無視できるもの と考えた.
次に, 可視化実験で得られた粗骨材粒子群とモルタル 相の挙動に関する画像デー夕に基づき, 各相のトレー サー粒子の速度ベクトルを算定する方法を説明する.

(1) 各相の着目トレーサー粒子として, 粗骨材粒子群 では人工軽量粗骨材粒子を, モルタル相では発泡スチ ロールの細粒を選んだ。これは, 画像データから各相の 流動状態を求める際, 映像が鮮明でかつ重心位置が簡単 に求められることがトレーサー粒子に要求されるからで ある.

(2) 透明な圧送管内を流動している可視化モデルコン クリートを，ビデオカメラとビデオデッキによって収録 する.このとき, 最小時間間隔 $1 / 100 \mathrm{~s}$ の夕イマーを用 いて，同時に収録画面に圧送経過時刻をスーパーイン ポーズする.

(3) 収録された画像デー夕を再生し, 所定の時刻ごと に画像を静止させる.モニター画像面上に透明板タイプ のデジタイザーを重ね, 静止画像面上の着目トレーサー 粒子の座標位置を, デジタルデータとして読み取り，接 続してあるマイクロコンピュータに入力する.

(4) 上記(3)の操作を, 読み込み時間間隔 $\Delta t$ ピッチで 繰り返し行う。この操作は, 着目トレーサー粒子が, ビ デオ画面上から消去するまで行う.

(5) 上記(4)の操作によって得られた着目トレーサー粒 子の軌跡を, 3 次のスプライン関数を用いで ${ }^{10)}$, 連続関 数に補間しこれを着目トレーサ一粒子の流跡線とする.

(6) 着目トレーサー粒子の圧送管内における速度べク トルは，流跡線上の任意の位置において，流跡線を時間 $t$ で数值微分することによって求められる. 図一3に, 流跡線と速度ベクトルの関係を示す．なお，テーパ管を 二次元的に表現するための座標系としては，管軸方向と 管軸直角方向からなる直交座標系を用いた。

(7) 速度ベクトルを管軸方向之管軸直角方向の速度成 分に分解する．管軸方向については，1 相系として流動 するとみなしたときに成り立つ連続の式から断面平均流 速を求める. 管軸方向の速度成分と断面平均流速との差 を管軸方向の変動速度とする.

1 相系ビンガム流体と仮定したフレッシュコンクリー

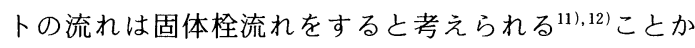
ら，テーパ管内の任意の位置での流線に直交する速度成 分は零である。また，本実験で用いたテ一パ管は管長

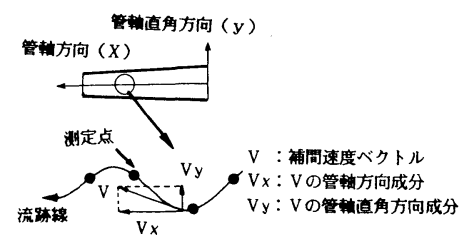

図一3＼cjkstart流跡線と速度ベクトルの関係 
$50 \mathrm{~cm}$ で管径を $\phi 155 \mathrm{~mm}$ から $\phi 100 \mathrm{~mm}$ に絞ったもの である.よって，層流状態における流線と管軸のなす角 度は, 最大で $0.0549 \mathrm{rad}$ (3.15 度) である.そこで, 本速度ベクトルの算定方法では，流線と管軸の方向は一 致すると仮定する. したがって, 管軸直角方向の速度成 分が直接, 管軸直角方向の変動速度となる.この速度べ クトルと変動速度ベクトルの関係については, 5.（1） 変動速度ベクトルの定義で説明する.

(8) 上記66および(7)の操作を行うトレーサー粒子の個 数は, 粗骨材粒子群およびモルタル相とも各 40 個程度 とした. その際, 圧送開始から圧送終了までにビデオ画 面上に現われるトレーサー粒子を経過時間および画面上 の位置において平均的に取り上げるようにした。

読み込み時間間隔 $\Delta t$ をあまり小さくとると, デジタ イザーの分解能の関係から誤差を増大させることにな り, 逆に $\Delta t$ を大きくとりすぎると, 着目トレーサー粒 子の微妙な挙動を取り込むことができなくなる.そこで, 本計測システムでは, 設定画面上で着目トレーサ一粒子 の流跡線を求めるのに要する座標位置のデー夕数が 20 個となるように読み込み時間間隔 $\Delta t$ を決定した。

3 次スプライン関数による補間の際に必要な端条件と しては, 補間関数の 2 階微係数が零であることとした.

実際の圧送管とビデオ画面上の圧送管は, カメラの ズームや圧送管のセッティングの関係から実物と同じ大 きさにならない場合が起こる，そこで，流速ベクトルを 計算するためには, ビデオ画面上の像と実像との寸法比 を正確に求めておく必要がある.

\section{4. 可視化モデルコンクリートの乱れ特性に対 する本計測システムの適用性に関する実験 的検討}

\section{（1）目 的}

本研究で開発した計測システムが, 可視化モデルコン クリートの変形性能を定量化するための計測システムと 成り得るかどうかを, 可視化実験によって得られた画像 データをもとに実験的に検討する.

これまで, 目視観察で定性的評価しかできなかった粗 骨材粒子群の微小振動やモルタル相の流速の乱れ等の挙 動を, 本計測システムで求められるトレーサ一粒子の速 度ベクトルによって定量的に評価する. 次に, 得られた 速度ベクトルに基づいて, フレッシュコンクリートの変 形性能を定量的に評価できる新しい指標を求め, 本計測 システムの有効性について検討する.

従来のフレッシュコンクリートのポンプ圧送性能に関 する実験的研究 ${ }^{51,6)}$ から，コンクリートの配合において 粗骨材とモルタルの容積比 $\left(V_{g} / V_{m}\right)$ が増加するに従っ て, テーパ管での圧力損失が増大し, ポンプ圧送性能が
低下することが知られている.

そこで, 本研究では小型ポンプモデルを用いて, テー パ管内流動に着目したポンプ死送実験を行った．可視化 モデルコンクリートを作成する祭，配合において粗骨材 とモルタルの容積比 $\left(V_{g} / V_{m}\right)$ を変化させることにより, テーパ管での流動状況が, 乱れ特性の少ない順調圧送状 態から, 乱れ特性が顕著に観察される閉塞発生に近い限 界圧送状態までを再現するようにした。そして，これら 一連の画像データについて, 本計測システムにより定量 的評価を行った。

\section{(2) 実験 概 要}

図一4に，ポンプ圧送実験に用いた実験装置の概要を 示す. 着目する管内流動部分は, 管長 $50 \mathrm{~cm}$ で管径が $155 \mathrm{~mm}$ から $\phi 100 \mathrm{~mm}$ に絞られたポリ塩化ビニール製 の透明テーパ管部である.

可視化モデルコンクリートの配合は, 表一1 に示す 4 種類である. 配合 1 は, 粗骨材とモルタルの容積比 $\left(V_{g} / V_{m}\right)$ が $20 \%$ であって，通常のコンクリートの配 合と比較すると極端に小さい，テーパ管内では，粗骨材 粒子群とモデルモルタル相の間に乱れが生じなく，1相 系流体の圧送状態を目標としたものである. 配合 2 と 3 は，順調圧送状態を目標とした配合であり，配合 4 は閉 塞限界の粗骨材とモルタルの容積比に近い配合で, 管内 閉塞発生に近い限界圧送状態を目標としたものである.

可視化実験に使用するモデルコンクリートは, 先に著 者らが提案したもの ${ }^{3)}$ と同じである. モデルモルタルに 使用する吸水性高分子樹脂の添加量は, 水 1 リットルに 対して $3 \mathrm{~g}$ とし, 全配合とも一定とした.この添加量は, 可視化モデルコンクリートの静的材料分離の程度が, ス

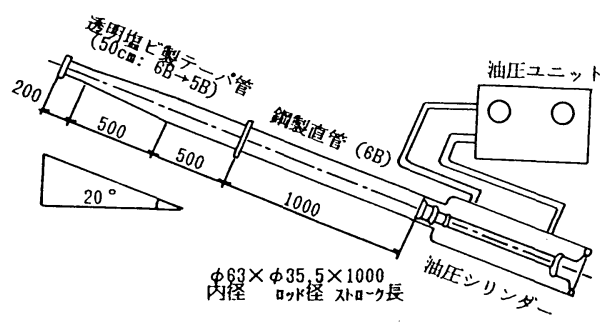

図一4 小型ポンプ圧送試験機

表一1 実験に用いた可視化モデルコンクリートの配合

\begin{tabular}{|c|c|c|c|c|c|c|c|c|}
\hline \multirow{2}{*}{ 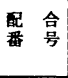 } & \multirow{2}{*}{$\begin{array}{c}\substack{\text { 意定 } \\
\text { スジフ } \\
(\mathrm{cm})} \\
\end{array}$} & \multirow{2}{*}{ 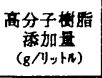 } & \multirow{2}{*}{$\begin{array}{c}\mathrm{V}_{g} / \mathrm{V}_{\mathrm{m}} \\
(\%)\end{array}$} & \multirow{2}{*}{$\begin{array}{c}\mathrm{VGI} / \mathrm{VGc} \\
(\%)\end{array}$} & \multicolumn{4}{|c|}{ 単位量 $\left(\mathrm{K} / \mathrm{m}^{3}\right)$} \\
\hline & & & & & w & $P$ & G 1 & G c \\
\hline e合 1 & 20 以上 & 3. 0 & 20 & 50 & 833 & 2.50 & 157 & 69 \\
\hline 眠合 2 & 14 & 3.0 & 60 & 50 & 625 & 1.88 & 177 & 309 \\
\hline 配合 3 & 12 & 3. 0 & 75 & 50 & 571 & 1.71 & 202 & 353 \\
\hline 现合 4 & 10 & 3. 0 & 85 & 50 & 541 & 1.62 & 217 & 378 \\
\hline
\end{tabular}


ランプ $12 \mathrm{~cm}$ 前後のフレッシュコンクリートと同程度 になることを想定したものである31. 粗骨材は，粗骨材 最大寸法を $25 \mathrm{~mm}$ とし, 5 15 $\mathrm{mm}$ の小砂利モデルは人 工軽量粗骨材を, 15 25 mm の大砂利モデルは, コー クスにアスファルトをコーティングしたものを用いた。 粗骨材モデルの粒度分布は, 人工軽量粗骨材とコークス の容積比 $\left(V_{G l} / V_{G c}\right)$ を $50 \%$ とし, 土木学会の $\mathrm{RC}$ 示 方書に規定されている範囲内に入るようにした。

モルタル相のトレーサー粒子としては, 直径 $3 \mathrm{~mm}$ 程 度の発泡スチロール粒子を使用した．発泡スチロール粒 子の比重は， 0.9 前後であるが，モルタルモデルの粘性 が十分高いためモルタルモデルと一体となって流動する ものとみなした．粗骨材相のトレーサ一粒子としては人 工軽量粗骨材のみとした。コークスは，形状が不規則な ため，ビデオ画面上で粒子の重心を決定することが困難 であり，他のトレーサー粒子と比較して読み取り誤差が 非常に大きいと考えられるため採用しなかった。

ピストンの圧送速度は， $3,6 \mathrm{~cm} / \mathrm{s}$ の 2 種類とし，圧 送実験は，同一条件で 3 回行った。各トレーサー粒子の 座標位置を取り込む際の取り込み時間間隔は, 圧送速度 が $3 \mathrm{~cm} / \mathrm{s}$ で $0.5 \mathrm{~s}, 6 \mathrm{~cm} / \mathrm{s}$ で $0.25 \mathrm{~s}$ とした。また，卜 レーサー粒子の流跡線の取り込み数は, 1 回の圧送実験 で約 40 本とし， 3 回の圧送実験のビデオ収録データか ら，少なくとも 100 本以上は取り込むこととした。

\section{(3) 実験結果および考察}

図一5〜8に，各配合別に，テーパ管軸位置に対する 各速度成分（管軸直角方向と管軸方向）の分布状況につ いて示す．テーパ管軸方向の速度成分については，流体 の質量保存則である連続の式から導かれる断面平均流速 と比較して示す。なお, 配合 1 では, 容積比 $\left(V_{g} / V_{m}\right)$ が $20 \%$ で，コンクリート中におけるモルタル相の占め る割合が大きく, ビデオ画面上においてモルタル相のト レーサー粒子である発泡スチロール粒子の像が明確でな かったために，モルタル相に関する速度べクトルは計測
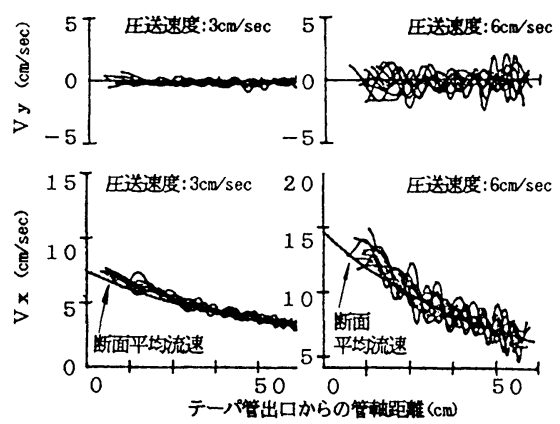

図一5 テーパ管軸位置に対する粗骨材粒子群の各速度成分の分 布状況（配合 $1: V_{g} / V_{m}=20 \%$ ）
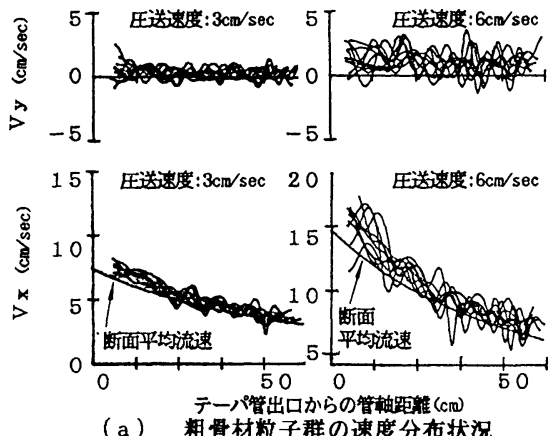

（a）粗骨材柆子群の速度分布状况

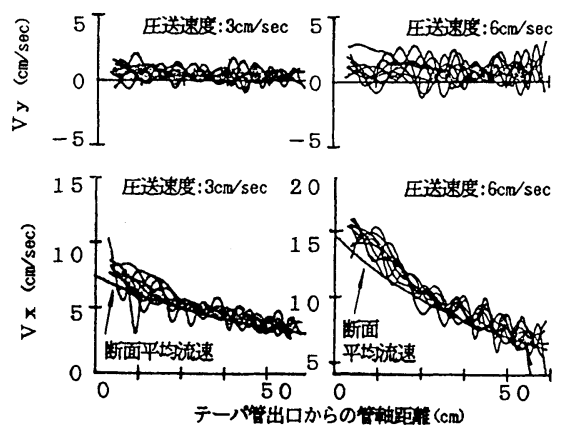

（b）モルタル相の速度分布状況

図一 6 テーパ管軸位置に対する各速度成分の分布状況

(配合 $2: V_{\boldsymbol{g}} / V_{\boldsymbol{m}}=60 \%$ )
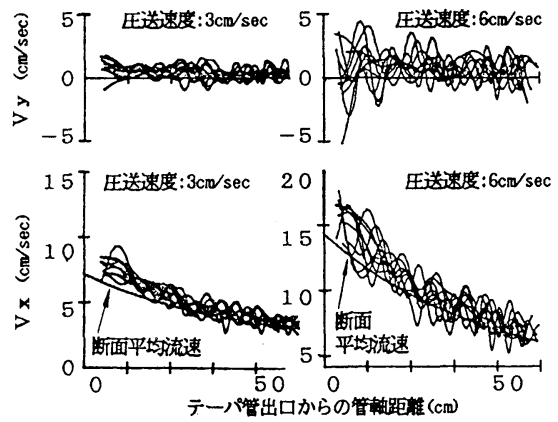

（a）粗骨材粒子群の速度分布状況
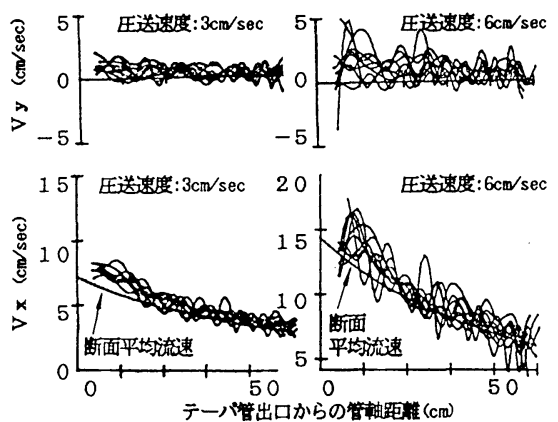

図一7 テーパ管軸位置に対する各速度成分の分布状況 (配合 $3: V_{\boldsymbol{g}} / V_{m}=75 \%$ ) 

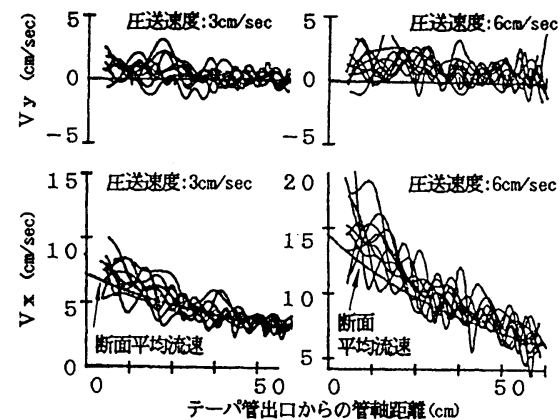

（a）粗骨材粒子群の速度分布状况
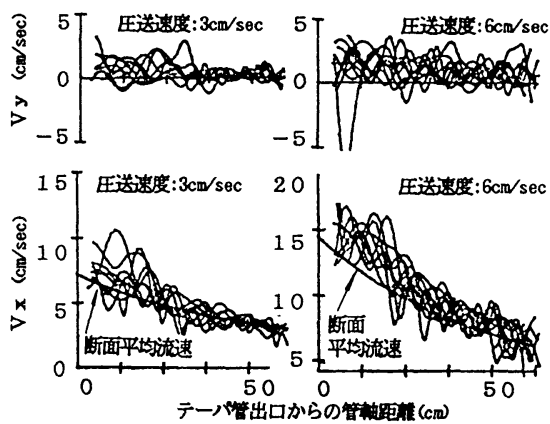

（b）モルタル相の速度分布状況

図一8 テーパ管軸位置に対する各速度成分の分布状況 (配合 $4: V_{g} / V_{m}=85 \%$ )

していない.

配合 1 では，圧送速度に関係なく，粗骨材粒子群の管 軸方向の速度成分は，断面平均流速の上下に分布してい るがその変動は小さく, しかも, 粗骨材相の流速分布の 各管軸位置での平均值と断面平均流速はほぼ一致すると いえる．管軸直角方向の速度成分については，原点を中 心として上下に分布しており, その平均値は零といえる. また， 2 相系流体の連続性から，今回計測できなかった モルタル相の流速分布についても, 粗骨材粒子群の速度 分布と同様な傾向があると考えられる。

このことより, 配合 1 のフレッシュコンクリートの テーパ管内流動状態は，粗骨材相とモルタル相の間に乱 れが生じていなく 1 相系流体の流れつまり栓流状態に近 いと予想される.

なお, 圧送速度について $3 \mathrm{~cm} / \mathrm{s}$ よりも $6 \mathrm{~cm} / \mathrm{s}$ の方が, 変動が大きくなっているが, これは, 圧送速度が大きく なりビデオカメラのシャッター速度 (1/60 秒) の関係 から，静止画面における着目トレーサ一粒子の画像が不 鮮明になってしまうためである．したがって，圧送速度 が異なる場合の速度成分の変動に関しては，定量的評価 は困難と考えられる。

次に，配合 2 から 4 では圧送速度に関係なく，粗骨材 粒子群およびモルタル相の管軸方向の速度成分は断面平
均流速のまわりに先の配合 1 よりも大きい変動幅で分布 している. また, 管軸直角方向の速度成分についても原 点まわりの変動が先の配合 1 よりも増大している．この 変動幅は, 同一配合で粗骨材粒子群とモルタル相の変動 幅とほぼ同じ程度である．これは，可視化モデルコンク リートの乱れ特性が粗骨材粒子群とモルタル相の間で発 生している現象であることを裏付けており，目視観察で の傾向と一致している．なお，連続の式から導かれる断 面平均流速が管軸速度成分の分布より若干下まわる傾向 および管軸直角方向の速度成分の平均が原点より少し大 きくなる傾向については，テーパ管寸法の製作誤差，計 測システムにおけるビデオ画面と実像の寸法比の精度, やデジタイザーによるトレーサー粒子の座標位置の測定 誤差等の影響によるものと考えられるが，本計測システ ムのこれからの課題の 1 つ之思われる.

各トレーサー粒子の管軸速度成分において断面平均流 速からの変動が増大する傾向は，テーパ管入口よりも出 口付近において顕著である。このことは，管内閉塞現象 がテーパ管出口付近に発生しやすいという実験結果と一 致しており，乱れ特性亡管内開塞現象が連続した現象で あることがわかる．また，各配合で比較すると，粗骨材 とモルタルの容積比 $\left(V_{g} / V_{m}\right)$ が増加するに従って, 速 度変動が増大する傾向は顕著である。このことは，容積 比 $\left(V_{g} / V_{m}\right)$ が増加するに従って, テーパ管内でのコン クリートの変形性能が低下するという実際のコンクリー 卜を用いたポンプ圧送の実験結果と一致しており，本計 測システムの妥当性を示している.

したがって,乱れ特性を解明することによって,フレッ シュコンクリートの変形性能と管内閉塞現象の 2 つの挙 動を結び付けることが可能であると考えられる.

\section{5. 変形性能を評価する指標の提案}

\section{（1）変動速度ベクトルの定義}

4. の実験結果から，配合における粗骨材とモルタル の容積比 $\left(V_{g} / V_{m}\right)$ が増加するに従って，また，テーパ 管入口から出口付近にコンクリートが流動するに従っ て, 各トレーサー粒子の管軸速度成分は断面平均流速か らより大きく変動することが明らかになり，この変動量 が乱れ特性の程度を示すと考えられる。本圧送実験に用 いた小型ポンプモデルでは，テーパ管部に圧送される前 の直管部におけるコンクリートの流動状態は固体栓流れ 之考えられ，粗骨材とモルタルの容積比 $\left(V_{g} / V_{m}\right)$ がい ずれの場合も断面平均流速とほぼ等しい．したがって， テーパ管内で各相のトレーサー粒子の管軸速度成分が断 面平均流速から変動する原因としては，テーパ管での断 面縮小に伴って，何らかの力がトレーサー粒子に作用す るためであると考えられる。この力は, 粗骨材粒子間, 
モルタル相内部, 粗骨材相とモルタル相の境界面, ある いは管壁之粗骨材粒子間や管壁とモルタル相間に発生す るせん断力と考えることができる．流体力学の分野にお ける乱流のレイノルズ応力に相当するものと考えられ る.

そこで，速度ベクトルの変動の程度と乱れ特性の関係 を検討するために，変動速度べクトルを，図一9に示す ように定義する．速度べクトルの求め方については，3.

（2）計測システムの概要で述べた. さらに，1相系の 流動（層流状態）では，管軸方向の速度成分しか存在せ ず，管軸直角方向には，速度成分をもたないことも示し た.

したがって，計測された流動状態を 1 相系の流動と比 較して，その違いを速度ベクトル上での変動として表わ すとすれば，管軸方向および管軸直角方向で各速度成分 の変動を求め，それを合成すればよいことになる。 その 際，1 相系の流動でも，テーパ管部のように管断面が変 化するところでは，管軸方向の断面平均流速が変化する ことを考慮するのは当然である。

これらを数式で表示すると

$V^{\prime}\left(t_{i}\right)=V\left(t_{i}\right)-\bar{V}\left(t_{i}\right)$

ここに, $V^{\prime}\left(t_{i}\right):$ 変動速度ベクトル

$V\left(t_{i}\right):$ 計測された速度ベクトル $\left(V_{x}, V_{y}\right)$ $\bar{V}\left(t_{i}\right): 1$ 相系流動が有する速度ベクトル

\section{$\left(V_{\text {ave, }}\right)$}

$t_{i}$ : 計測時刻

となる。

これより, 変動速度ベクトルが零ベクトルということ は，補間速度べクトルと断面平均流速ベクトルが一致す ることになり，4．の配合 1 に近い流動状態を意味する.

図一10 12 は，4. の実験結果について，各配合別に 変動速度ベクトルの分布状況を表わしたものである．た だし，計測したすべての流跡線上の変動速度ベクトルを 表わすと図が繁雑になるため, 代表的な流跡線 5 本につ いて得られたもののみを示した。

圧送速度が $3 \mathrm{~cm} / \mathrm{s}$ の場合は, ベクトルの大きさを, $0.00 \sim 1.33 \mathrm{~cm} / \mathrm{s}, 1.33 \sim 2.67 \mathrm{~cm} / \mathrm{s}$ および $2.7 \mathrm{~cm} / \mathrm{s}$ 以 上の 3 段階にランク分けし二次元的に表現した. 同様に， 圧送速度が $6 \mathrm{~cm} / \mathrm{s}$ の場合は, ベクトルの大きさを, $0.00 \sim 2.67 \mathrm{~cm} / \mathrm{s}, \quad 2.67 \sim 5.33 \mathrm{~cm} / \mathrm{s}$ および $5.33 \mathrm{~cm} / \mathrm{s}$ 以上の 3 段階にランク分けした。

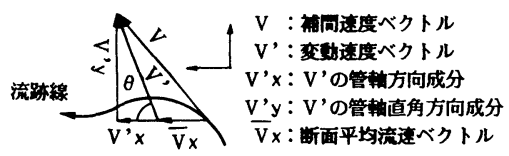

図一9変動速度ベクトルの定義
配合 1 と他の配合のものを比較すると, 配合 1 では変 動速度ベクトルは非常に小さいものしか存在しない。こ れは, 乱れ特性の程度が小さく，粗骨材粒子群がほぼ断 面平均流速と一致して流動していることを示すものであ る.

配合 2 と 4 では，全体として変動速度ベクトルが大き くなっている. しかし，ベクトルの大きさを類別すると， 変動速度ベクトルの大きいものほぼ発生数は少ないが, テーパ管出口付近に集中しているのが認められる。これ に対して, 変動速度ベクトルの小さいものほど, テーパ 管全体にわたって多数発生している．また，粗骨材とモ

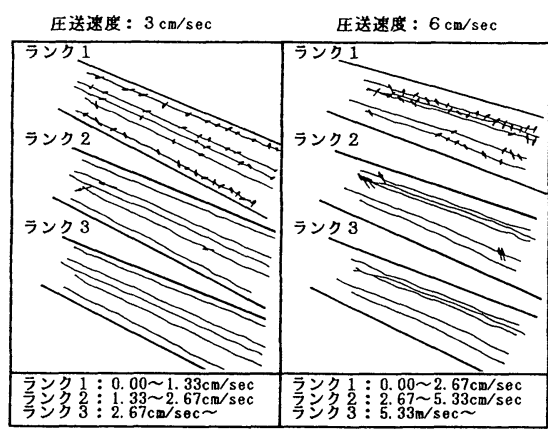

図一10 テーパ管内の変動速度ベクトルの分布状況 (配合 $1: V_{g} / V_{m}=20 \%$ )
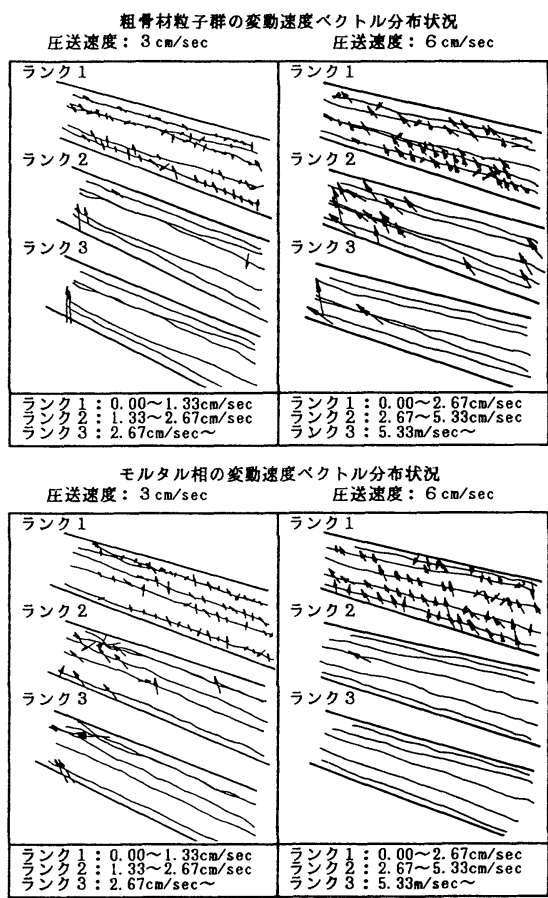

図一11 テーパ管内の变動速度ベクトルの分布状況 (配合 $2: V_{g} / V_{m}=60 \%$ ) 

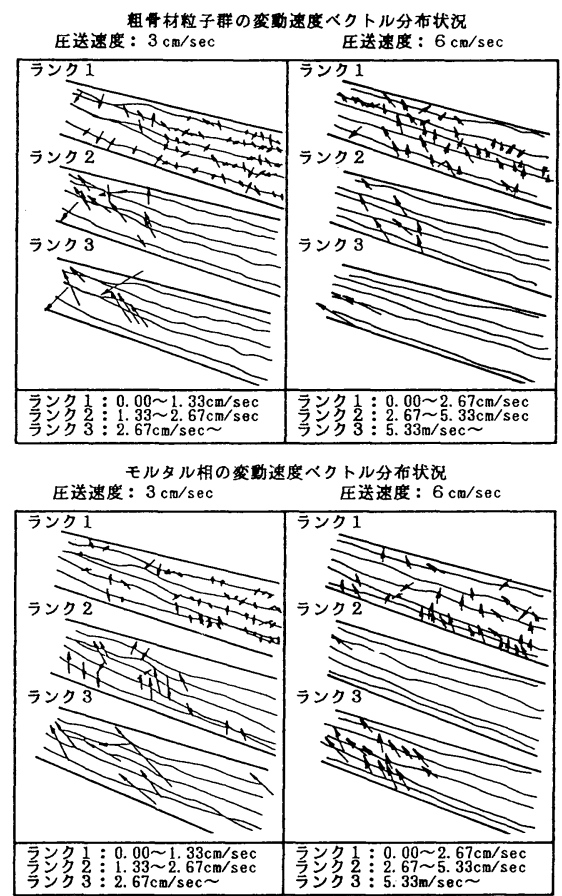

図一12 テーパ管内の変動速度ベクトルの分布状況

(配合 $4: V_{g} / V_{m}=85 \%$ )

ルタルの容積比 $\left(V_{g} / V_{m}\right)$ が増加するに従って, 大きい 変動速度ベクトルがテーパ管出口付近に多数発生するよ うになっている．ただし，小さい変動速度ベクトルの分 布状況には差がみられない。これから，大きい変動速度 ベクトルの発生頻度や発生位置が，管内閉塞現象やフ レッシュコンクリートの変形性能に大きな影響を与えて いるものと考えられる.

以上の考察から, 乱れ特性の程度を評価する指標とし て, 大きい変動速度ベクトルの分布状況（発生位置およ び発生頻度）が有効である.

\section{（2）平均変動加速度の定義}

変動速度べクトルの分布状況は二次元的であり, その ままでは，乱れの程度を定量的に評価する指標としては 必ずしも適当でない，そこで，変動速度べクトルの分布 状況を定量化する指標として, 次式で定義される物理量 $F$ を導入する. $F$ の物理的意味は，テーパ管軸方向の ある区間中での各相のトレーサー粒子の変動加速度の平 均値である．これは，着目トレーサ一粒子に作用する力 は, 乱れ特性によって発生する内部応力に起因している ことと, 着目トレーサー粒子個々の質量がほぼ一定とみ なすことが可能という仮定に基づいて導かれている.

$$
F=\frac{1}{n} \sum \frac{\left\|\left\{V^{\prime}\left(t_{i+1}\right)-V^{\prime}\left(t_{i}\right)\right\}\right\|}{\Delta t}
$$

ここに, $n$ : 区間内のデー夕数
$\Delta t$ : 補間時間 $\left(t_{i+1}-t_{i}\right)$

$\|V\|$ : ベクトル $V$ の長さ，絶対値を表わす.

図一13 は，テーパ管軸位置に対して，式（2）で求 められた平均変動加速度 $F$ の分布状況を示したもので ある.限界閉塞容積比である配合 4 になると,急激にテー パ管出口付近で大きくなっている.

また，物理量 $F$ にその区間での平均質量を乗ずると 変動を生じさせている力と考えることができる，1 相系 の流動では, $F=0$ となり, 変動を生じさせる力は存在 しないことになる。これを考慮すると，テーパ管出口付 近では, 粗骨材相とモルタル相に発生する内部応力が大 きくなっていることが推測される.

この内部応力が, テーパ管内における可視化モデルコ ンクリートの乱れ特性による圧力損失であり，この内部 応力がある限界を越えると, 粗骨材粒子群のアーチング 現象を誘発する可能性が大きくなり, 閉塞現象に至ると 考えられる.

\section{6. 結 論}

本研究は，これまで明らかにされていなかったフレッ シュコンクリートの管内流動状態における変形性能を定 量的に評価することを目的として，まず，可視化モデル コンクリートにおける粗骨材粒子群とモルタル相の速度 ベクトル分布を計測するシステムを開発した.

次に，可視化実験手法による実験室規模の小型ポンプ 圧送実験を行い, 開発した計測システムを用いて,フレッ シュコンクリートのテーパ管内流動状態における粗骨材 相とモルタル相のトレーサー粒子の速度ベクトルを求 め, 乱れ特性の程度と変形性能の関係について実験的に 検討し, 変形性能を定量的に評価する指標を提案した。

以下，本研究において明らかになったことを述べる。

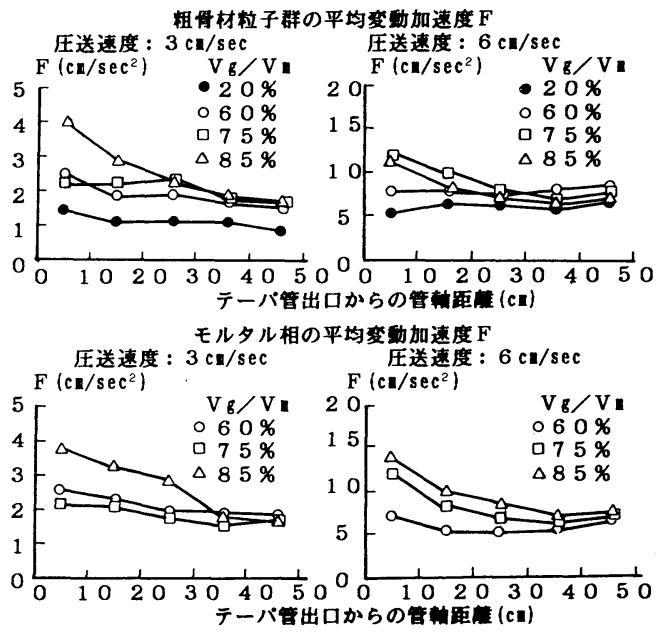

図一13 テーパ管軸位置に対する平均变動加速度 $\boldsymbol{F}$ の分布状況 
（1）可視化モデルコンクリートのポンプ圧送実験に おける圧送管内部の状況を記録・解析する新しい方法と して, 市販用ビデオシステムと透明板タイプのデジタイ ザーおよびマイクロコンピュータを組み合わせたシステ ムを考案した.この結果, 従来の管内流動に関する測定 システムでは計測不可能であった, 粗骨材相とモルタル 相の速度ベクトルを計測できるようになった。

（2）テーパ管の管内流動に着目したポンプ圧送実験 を行った結果, 本研究で開発した計測システムによれば, 乱れの小さい一様流れから, 管内閉塞現象が発生しやす く乱れ特性が頻繁に生じる限界圧送状態まで, 粗骨材相 とモルタル相のトレーサー粒子の速度ベクトルを計測す ることができる.

（３）可視化モデルコンクリートの乱れ特性を評価す る指標として, 本計測システムによって求められる速度 ベクトルと断面平均流速ベクトルとの差によって定義さ れる変動速度ベクトルおよびその分布状況（発生位置と 発生頻度）は有力である.

（4）乱れ特性によって発生する内部応力に対する指 標としては, 変動速度ベクトルから求められる断面の平 均変動加速度が有効である。

今後の課題としては, 本研究で開発された計測システ ムを用いて,テーパ管以外の変形管 (ベント管や分岐管) において可視化モデルコンクリートの管内流動状態を検 討する必要がある．また，ポンプ圧送性能の評価方法に 最も重要である管内閉塞機構の解明にあたり, 管内閉塞 に直接関係する乱れ特性が, どのような過程を経て閉塞 に至るのかを詳細に検討する必要がある.

本計測システムによって新しく得られた乱れ特性やそ の評価指標は，可視化実験手法を用いたコンクリートモ デルにおいて成立するものである，したがって，これら の知見が実際のフレッシュコンクリートの管内流動状態 に適用可能かどうかについては, 今後さらに, 検討して いく必要がある.

謝辞: 本研究をまとめるにあたり, 東京大学工学 部 岡村 甫教授, 前川宏一助教授には, 有益なご援助,

ご指導を頂きました。ここに深く感謝の意を表します。

参 考 文 献

1) 田沢栄一：ポンプ圧送技術の現状と問題点, コンクリー 卜工学, Vol. 21, No.11, pp.13 22, Nov. 1983.

2）土木学会：コンクリートのポンプ施工指針 (案), 昭和 60.11.

3）橋本親典・丸山久一・清水敬二：フレッシュコンクリー 卜の管内流動における閉塞過程の可視化に関する実験手 法, コンクリート工学, Vol. 26, No. 2, pp. 119 127, Feb. 1988.

4）堀口和弘・橋本親典・熊崎 稔・中村裕剛：フレッシュ コンクリートの管内流動における可視化実験に関する研 究, 土木学会第 41 回年次学術講演会講演論文集第 5 部, pp. $473 \sim 474$, 昭和 61.11 .

5）橋本親典・堀口和弘・丸山久一：管内流動中の粗骨材相 とモルタル相の流速ベクトル分布計測システムの開発, 土木学会第 42 回年次学術講演会講演論文集第 5 部, pp. 562 563, 昭和 62.9 .

6）井上 建・橋本親典・中村裕剛：フレッシュコンクリー 卜の管内流動における動的材料分離の定量化, 土木学会 第 42 回年次学術講演会講演論文集第 5 部, pp. $560 \sim 561$, 昭和 62.9.

7）大西精治・橋本親典・原田健二 : ポンプ圧送時のコンク リートの変形性に関する基砋的研究, 第 7 回コンクリー 卜工学年次講演会講演論文集, pp. 325 328, 1985.6.

8）烏田専右・森永 繁ほか：コンクリートポンプの管内圧 送圧に関する研究一その 2 実際のポンプを用いた圧送㬰 験一, 日本建築学会論文報告集, 第 178 号, pp. 11 16, 1977. 12 .

9）橋本親典・二羽淳一郎・原田健二：流動化コンクリート のスランプロスがフレッシュコンクリートの変形性に及 ぼす影響，セメント技術年報，No. $39 ， p p .186 \sim 189$, 1982.5 .

10）市田浩三・吉本富士市：シリーズ新しい応用の数学 20 スプライン関数とその応用, 教育出版（株), pp. 43 59, 1979.6.

11）岩崎訓明：コンクリートの特性, 共立出版, pp. 18 21, 昭和 57.6.

12）村田二郎・岡田 清：最新コンクリート技術選書 1 フ レッシュコンクリートのレオロジー・コンクリートの弾 性とクリープ, 山海堂, pp. 53 69, 昭和 56.5.

(1988.2.25 - 受付) 